\title{
高密度住宅地における密度と児童の交遊 (I)
}

（高密度居住環境の社会生態学的検討）

正会員川道 麟太 郎*

\section{本論の構成}

標題の研究を，下記の目次にしたがい 2 篇に分けて報 告する。

$$
\text { 第一篇 }
$$

\section{$\$ 1$ 研究の目的と方法}

$\S 2$ 調查の概要

$\$ 3$ 分析の枠組

$\$ 4$ 各地区の児童に関する一般的分析

$\$ 5$ 非物理的要因別の検討

$\$ 6$ 住宅条件別の検討

第二篇

\section{$\$ 7$ 既成住宅地に打ける密度と交遊の変動}

7.1 交友人数纪ついて

7.2 交友構造要素について

7.3 䚻宅後の遊び時間について

7.4 戸外の遊び場所について

7.5 住宅立地条件別の変動

$\$ 8$ 計画団地における密度及び空間的条件の相違に よる交遊の変動

8.1 密度と交遊の変動

8.2 住棟形態別の変動

8.3 住棟配置形式別の変動

8.4 高層住棟における階位別の変動

\section{$\S 9$ ま め}

\section{$\S 1$ 研究の目的と方法}

密度に関する研究は, 元来, 生物と環境の関係を問題 にする生態学の分野において, 実験的方法や野外調查に 基づいて進められてきた。そこでは，個体群生態学にお ける密度効果に関する理論注1) や動物比較行動学での個 体群密度 (population density 以後, 本論で言う密度は この密度である) の影響による集団の病理的現象の把握 等によって一定の成果がおさめられている。人間に関す る研究としても, 都市社会学に打けるパーク, バージェ スらのいわゆる人間生態学派の人達による都市の社会病 理や都市構造に関する仕事以来, 生態学で得られた知見 をもとに, シュミット, ウインスボロウ, ガルらによっ て都市の密度や住宅の居住密度と住人の病理現象の関係

* 関西大学工学部・専任講師

(昭和 52 年 5 月 16 日本稿受理 ・討論期限昭和 53 年 5 月末日)
を, 都市的統計データを用いて捉えようとする研究が多 く行われてきた。また近年, 住宅の居住密度と家族成員 の生理, 心理, 人間関係などの関係をみたプラント,ガ ンス, ローリング, ミッシェルらの研究や, 遊歔室や作 業室などの部屋レベルの密度とそこでの人の対人的, 対 物的行動を細かく調べたハット，マクグロー，ルー, フ リードマンらの実験的研究が数多く報告されている注2)。 これらの研究は, 大方は高密度な人間環境の出現という 現実世界の問題を踏まえるとともに，密度を人間とその 環境の関係を探る媒介的概念に用い上うとする視点を併 せもっている。しかしこれらの密度に関する研究も, 居 住密度と家族成員の関倸をみた研究を除けば, そのほと んどはマクロな都市の統計データを用いた研究である か，あるいは部屋レベルでの実験的研究である。日常的 な生活の拡がるいわばミドル・レンジな範囲での研究は， 現実場面での把握方法の困難さがネックになって比較的 手薄になっている。しかし，現実の環境を計画的な立場 に立って論じようとする場合は，どうしても都市的なマ クロな研究と実験室的研究の間を埋めておく必要があ る。そこで筆者らはそのような観点から，児童の日常生 活圈とみられる校区圈あるい街区圈に招ける密度と児 童の日常的な交遊生活の関倸に注目してみることとし た。交遊生活を取り上げるのは, 密度の関連を人と人と の相互作用の側面に関して捉えたいと考えているためで ある。また児童を対象とするのは，児童の場合は成人と 異なり, 住宅地の一定圈域にその日常生活がほぼ完結し ており，その地区条件が児童に比較的強く作用するもの と考えられることと，交友関係や就遊の状況を問う相手 として, 児童からは比較的率直な回答を求めやすいと考 えたためである。

我国の建築，都市計画の分野でも，人間関係と住宅地 の街区形式や集合住宅の形態などとの関係をみた研究は 多い。それらの中には，児童密度や戸数密度と児童の交 友の関連を指摘したものもある注3)。接触しやすいこと が，交際を動機付けたりそれを増す要因になることも， しばしば指摘されている注4)。それらから，人が互いに 近い状態に分布していること，すなわち密度の高さと人 の交流の関係を関連付けて考えてみることができる。人 がまわりにほとんどいないような密度では，人は交流を 
もとうとしてもそれは困難であるが，密度が高くなると 交流はしやすくなる。しかし一方, 高密度に人々が集中 する大都市では「孤独なる群集」や「都市の中の孤独」 といったことが言われる。人々を詰め込んだ混み合5空 間では，人どうしの友好的な交流関係は減少すると言わ れている注5)。密度が極端に高くなると，それは人の相 互交流のむしろ阻害要因になることが考えられる。

動物生態学の分野では，げつ蒾類動物を用いた実験や 野外調查から，過度な密度は個体やその集団に悪影響を 及ぼすことが報告されている注6)。それは，食糧の不足 や単に生活環境の悪化によるものではなく，個体間相互 の過㮃な相互作用によって引き起こされるものであると されている。動物社会に掞ける個体間の相互作用と密度 の関倸を理論的に説明しているものの一つに，アリーの 原理と呼ばれるものがある。アリーは，社会的集合をす る動物の個体間には生理的な相互作用が働いており，そ れが不足するような過蹯の状態も過㮃になるような過密 の状態もともに個体群に悪い影響を及ぼし，それらの中 間に個体群㳊適な密度域が存在して,この最適密度の 高い動物ほど一般に社会化傾向が強いとする注7)。

筆者らはこれらの知見をもとにして，今回の研究に先 だって, 過柾から過密と呼ばれる全体的な密度範囲の中 でいくつかの住宅地を取り上げ，そこでの児童の交友人

\section{表一1 調查対象地区の概要}

\begin{tabular}{|c|c|c|c|}
\hline 対象地区 & 生 野 地 区 & 伝 法 地 区 & 中浜地 区 \\
\hline 調查対象校 & $\mathrm{A}$ 小, $\mathrm{B}$ 小, $\mathrm{C}$ 小 & 伝 法 小 & 中 浜 小 \\
\hline 人 総人口 & 27558 人 & 17887 人 & 10957 人 \\
\hline 児童数 & 2204 人 & 1704 人 & 937 人 \\
\hline 地区総面皘 & 91 ha & $59 \mathrm{ha}$ & ${ }^{*} 84 \mathrm{ha}$ \\
\hline $\begin{array}{l}\text { 人口密度 } \\
\text { 七名品 } \\
\text { (人/ha) }\end{array}$ & $\begin{array}{ll}\text { 全 体 } & 338 \\
\mathrm{~A} \text { 小校区 } & 285 \\
\mathrm{~B} \text { 小校区 } & 341 \\
\mathrm{C} \text { 小校区 } & 388\end{array}$ & $\begin{array}{ll}\text { 全 体 } & 418 \\
\text { 既成住宅地 } & 301 \\
\text { 府 営 団 地 } & 581 \\
\text { 市営 団 地 } & 673 \\
\text { 公団千鳥㮃 } & 892 \\
\text { 公団 伝法 } & 955\end{array}$ & $\begin{array}{lr}\text { 全 体 } & 417 \\
\text { 既成住宅地 } & 353 \\
\text { 公団森之宮 } & 1103 \\
\text { (第一団地) } & \end{array}$ \\
\hline 地区の位置 & 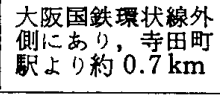 & 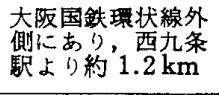 & 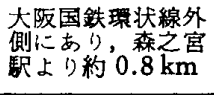 \\
\hline 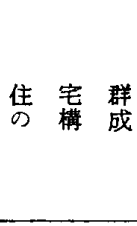 & 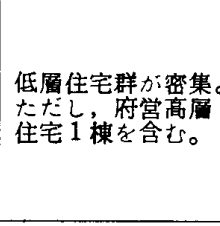 & 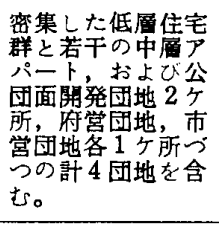 & 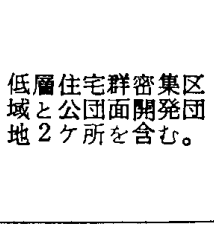 \\
\hline 地 区 & 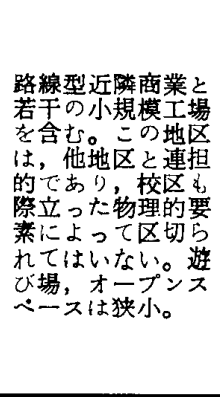 & 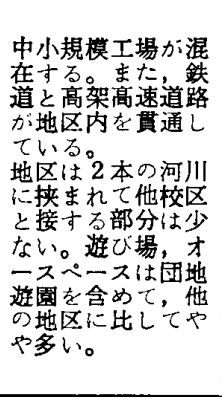 & 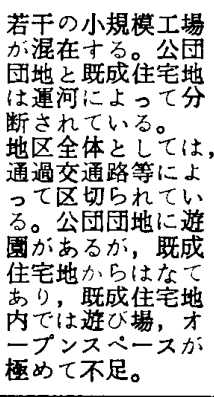 \\
\hline
\end{tabular}

\footnotetext{
“地下鉄ならびに国鉄理状線の車車用地を含む。
}

数と密度の間にある変動傾向を調べた注8)。その結果は， 密度の低いところから密度が上昇するにつれて交友人数 は增えるが，ある密度の範囲を越えればそれ以上では密 度が上がっても交友人数は増えないか, ないしは隇少す る傾向がみられるというものであった。そこで，今回， 更に高密度域に焦点を絞って, そこでの密度と交遊の変 動関係を, 交友人数, 友達の学年構成, その地理的分布 などの交友関係や遊びの時間や場所といった就遊状況に ついてみてみることとした。

本研究の目的は, 生態学で言われる密度効果の理論が 人間界に扔いても拡張できるかどうかを，特に日常的場 面における社会的相互作用の側面に注目して検討しよ5 とするものである。

\section{$\S 2$ 調查の概要}

\section{1 調査地区の概要}

調查対象地区は，図一1に示すように大阪市内の高密 度住宅地の中から国鉄環状線外周部にある 3 地区をとり あげ，そこにある 5 小学校を調查対象校とした。3 地区 の概要は表一1 に示すとおりである。伝法地区と中浜地 区は既成住宅地区域が高密度であるとともに，高密度な 計画団地を含む地区として選定し，生野地区は高密度な 既成住宅地であるが，そこの中でも段階的に密度の異な る3校区のある地区として選定した。伝法地区は住宅公 団面開発団地の伝法団地と千鳥橋団地の 2 団地及び府営 と市営の公営 2 団地を, 1 校区の中に含む地区である。

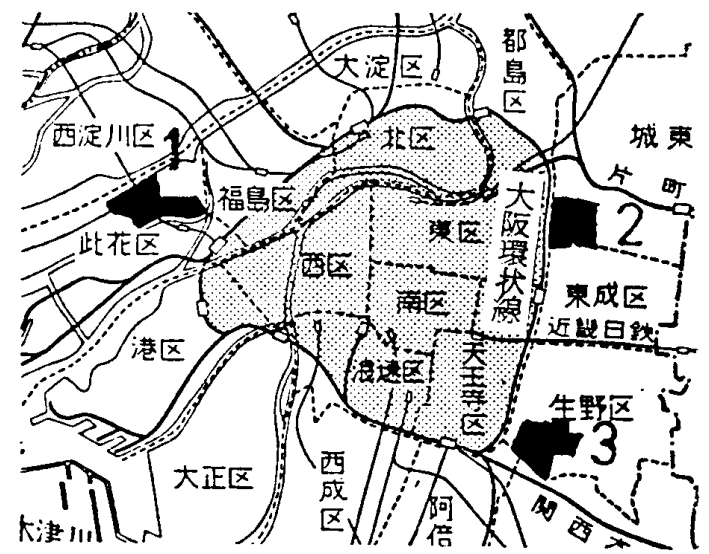

\section{1：伀法地区 2：中浜地区 3：生野地区 図一1 調查地区の位置}

表一2 調查紙の回収および有効数

\begin{tabular}{|c|c|c|c|c|c|c|}
\hline 対 & 象 & 校 & $\begin{array}{l}4 \cdot 5 \text { 年 } \\
\text { 児童 数 }\end{array}$ & 回収数 & 有 効 数 & 考 \\
\hline & \multirow{4}{*}{ 野 } & 計 & 700 & 511 & 477 & \multirow{4}{*}{ 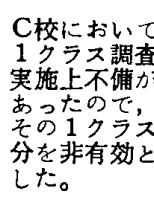 } \\
\hline & & A & 166 & 166 & 164 & \\
\hline & & B & 336 & 150 & 150 & \\
\hline & & $\mathrm{C}$ & 198 & 195 & 163 & \\
\hline 伝 & & 法 & 512 & 511 & 506 & \multirow{3}{*}{ 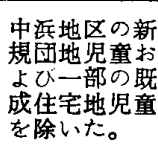 } \\
\hline 中 & & 捠 & 273 & 265 & 245 & \\
\hline 総 & & 部 & 1485 & 1287 & 1228 & \\
\hline
\end{tabular}


中浜地区は運河を中央にして，その西側に住宅公団面開 発団地の森之宮第一並びに第二団地があり，東側に既成 住宅地のある 1 校区の地区である。生野地区は 3 校区の 区域間に, 通過道路や河川等の特別な物的境界要素のな い連続的な地区である。

\section{2 調查の方法}

調查対象 とする児童は，日常行動の校区圈への拡が り, 調查に対する回答能力, できるだけ学年差の無い範 用で多くの回収数を得ることを勘案して，4 年生と 5 年 生の児童全員とした。方法は質問紙法によるもので, 各 小学校のクラス担任の先生に依頼し, 学校の時間内でク ラスごとに一斉に児童に回答を求めた。質問の内容は， 帰宅後の通常よく遊ぶ友達の人数（質問の表現によって 回答人数に相違がみられるが，ここでは「学校がおわっ て家に帰ってからふふだんよくいっしょに遊ぶ友達〔だ いたい週に 3 回から 4 回以上はいっしょに遊ぶ友達」」) を尋ねた。次いで, それらの友達の名前, 学年, 住所の 区域を書かせた。ただしこの名前を書かせるのは，児童 個々の回答時間にあまり差がでないようにするために 7 人までとした。したがって，先の問で友達人数を 8 人以 上の数值で答えている児童については，中でもよくいっ しょに遊ぶ友達 7 人までのそれらを書かせることとした （なお，以前の調查結果から 8 人以上の友達がいる児童 は，全体で 1 割を越えないと予測した)。その他，雨でな かった調查日前日（平日）の帰宅後の住戸内外の遊び時 間，普段の遊び場所それに子供会などの地域団体活動一 の参加と不参加, ビゅくとけいこごとにいっているかど らか及びそれらの頉度などを尋ねている。調査は, 昭和 51 年 10 月中旬から 11 月中旬にかけての前日が日祝日 でない日に実施した。

\section{3 調查紙の回収及び有効数}

回収及び有効数のうちわけは表一2 に示すとおりであ る。 4,5 年生の悉皆調查を意図したが， 5 校の内生野地 区のB校のみでは学校の都合により各学年 2 クラスずつ の部分調査になった。また，同校では住所名簿の閲覧が できず，交友の相手を地図上に記入してその地理的分布 をみる資料を作成することができなかった。中浜地区で は森之宮第二団地の入居開始後の日が浅く，そこに住む 児童々既成住宅地からかけ離れた一部区域の若干数児童 を有効からはずすものとした。

\section{\$3 分折の枠組}

主たる目的は, 地域の密度及び空間的条件と児童の交 遊の関係をみることである。しかし, 児童の個人的, 社 会的条件も相当に児童交遊を規定すると考えられるの でまず，それらに関連した検討を行う（ただし，今回 の調査では児童の個人的気質等にまでは立ち入っていな い)。次に目的の検討を行うが, 既成住宅地と計画団地 では密度水準や空間的条件に相当の相違があるので，そ れらは別々に検討することとした。

分析は児童の個人的, 社会的要因並びに地域と住宅に おける密度及び空間的条件を説明変数側におき, 児童交 遊に関して得られた各種 データを被説明変数側におい て, 前者の相違や変化が後者の変動にどのように関連し ているかをみていく方法ですすめる。そのために，説明 変数側の各項目, 各カテゴリーと被説明変数側の児童交 遊の各種データの間の関連データ表を作成した。児童の 個人的, 社会的要因については, 学年, 性別, 地域団体 活動への参加の有無, じ沙くとけいこごとの有無, きょ らだい人数の各項目を取り上げた。密度に関しては㜔童 の日常行動圈をべースとする見方から，主として校区レ

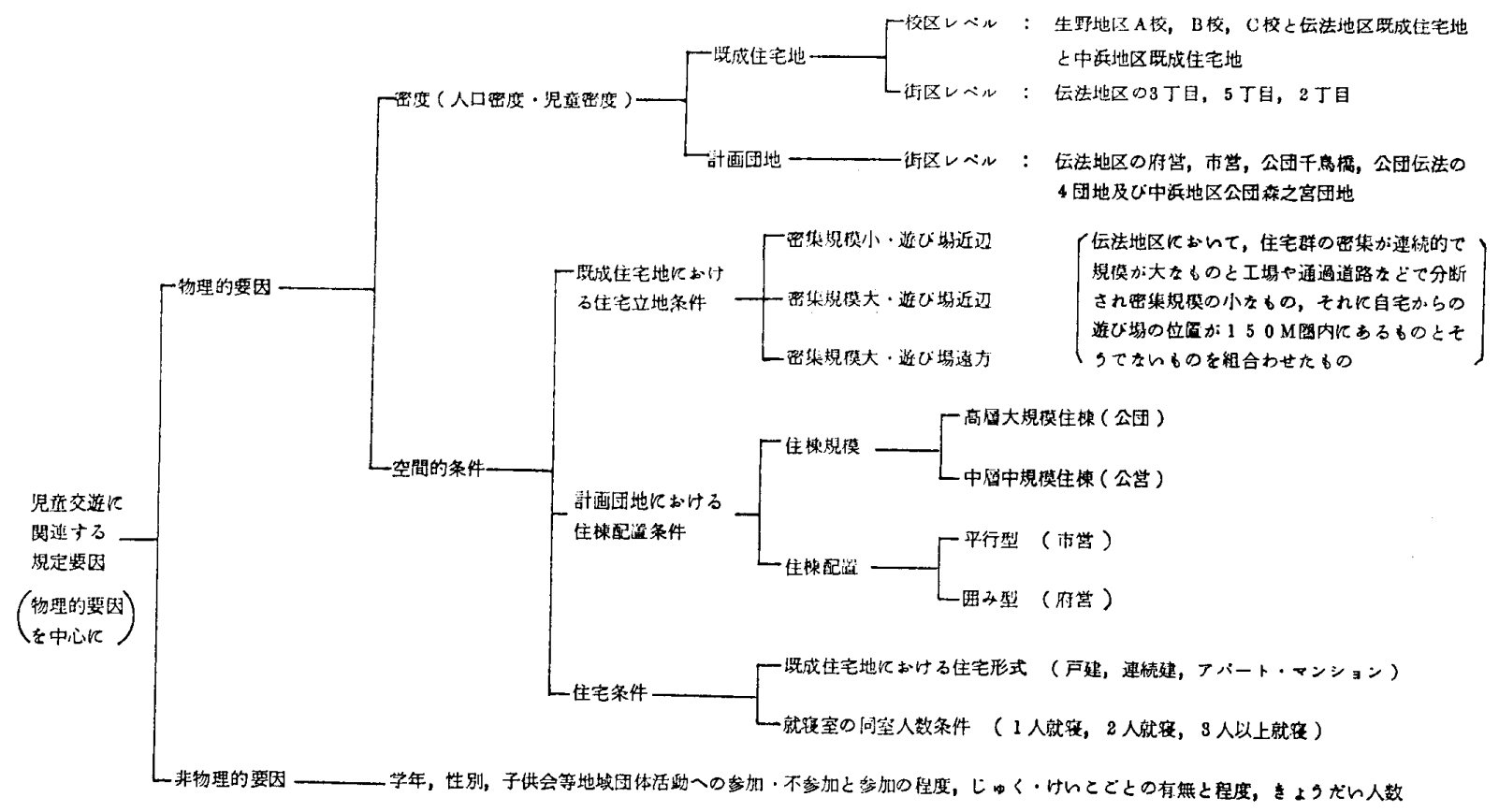

図一2 児童交遊を規定する要因 
ベルと街区レベルの密度に注目し, 補足的に住宅におけ る混み合いを児童の同室就寝人数を指標としてみてみる こととした。地域に関する密度は, 児童の利用が可能な 遊び場用地や関連施設用地を区域面積に含むセミグロス 密度を採用している。地域や住宅の空間的条件として は, 既成住宅地における住宅立地条件と住宅形式の相 違, 計画団地における住棟形態, 住棟配置形式, 高層住 棟の階位の相違を比較項目として取り上げている。以上 が説明変数側におく各要因の項目であり,それらの全体 的関係は図一2 に示すとおりである。被説明変数側にお く児童交遊については, 児童の交友関係を人数, 学年構 成, 地理的分布に関してそれぞれ類型的に分けて指標化 し, それに就遊の現況としての遊び時間, 遊び場所を加 えて全体を構成している。交友人数は, 調查した全児童 の交友人数平均值 3.8 人を中央にして $3 \sim 5$ 人を中間的 な交友人数と決め, その両側を 2 段階へうう分けて孤独 型（友達無し）, 少人数型 (1 2 人), 中間人数型 (3〜 5 人), 多人数型 ( $6 \sim 9$ 人), 特別多人数型 (10 人以上) の 5 段階分類を行った。なお，多人数なものを 9 人以下 と 10 人以上で分けたのは, 10 人以上の各值で全児童の 交友人数相対度数が $1 \%$ 以下になるのでそれを一応の 目安としたことによる。学年構成は, 同学年を中心とす るよこ型と, 異なる学年を多く含むたて型に大別し, 更 に, よこ型は全員が同学年である全同学年型とほとんど が同学年 (同学年比率 $2 / 3$ 以上 1 末満) である同学年中 心型に，たて型は異なる学年と同学年を同学年に片寄る ことなく含む通学年型と同学年を全然含まない無同学年 型に分けて 4 分類した。地理的分布については, 交友圈域 の近隣圈, 至近圈を設定して類型化することにした。近 隣圈はここでは調查地区内にあるいずれの団地も団地内 の最も離れた棟どらしの距離が $150 \mathrm{~m}$ を最大にしそれ
を越えることがなく，団地内交友を近隣圈交友とすると ころから，自宅から $150 \mathrm{~m}$ 圈内に友達の自宅がある場 合を近隣圈の交友とすることにした。また，既成住宅地 についても街区レベルの区画割等とその值が特に矛盾す ることはないので，全体を通じて $150 \mathrm{~m}$ を近隣圏の距 離として用いることとした。なお，既成住宅地について は，児童の自宅間の実質的歩行距離をとることにしてい る。至近圈は団地については同一棟, 既成住宅地につい ては近隣圈距離の半分の $75 \mathrm{~m}$ を用いることとした。こ れらの近隣圈, 至近圈を規準にして, 地理的分布は, 集 中型と分散型に大別し, 集中型は至近圈内に友達全員が 含まれる至近型と近隣圈内に全員が含まれる近隣型に， 分散型は近隣圈とその外の両方に分布する混成型と, 全 員が近隣圈外に分布する遠方型に分けて 4 分類した。そ の他, 唚宅後標準型, 特殊型, 学校交友延長型を指標化 し分析に用いている。それらの規準や全体的関係は図一 3 に示寸とおりである。なお，ここでは「交友」は児童 の友達関係を,「交遊」はそれに就遊状況を加えた児童 の全般的な遊び生活を指す意味で，それぞれを用いてい る。

\section{§4 各地区の児童に関する一般的分析}

各種要因別の児童交遊の比較検討を行う前に, 各地区 における地域活動状況や住宅における同室就寝の状況な どを概観し，次いで，児童の交友人数分布と遊び時間分 布の一般的傾向をみておく。

\section{1 各地区の児童の特徵}

表一3 は, 各地区児童の地域活動参加状況等をみたも のであるが，その表の表頭にある各項目について，それ ぞれ地区間の比較を行う。

（1）校区外交友比率校区外の児童と交友を行。 ている児童の比率は，生野地区で $10 \%$ 強あり，他の 2

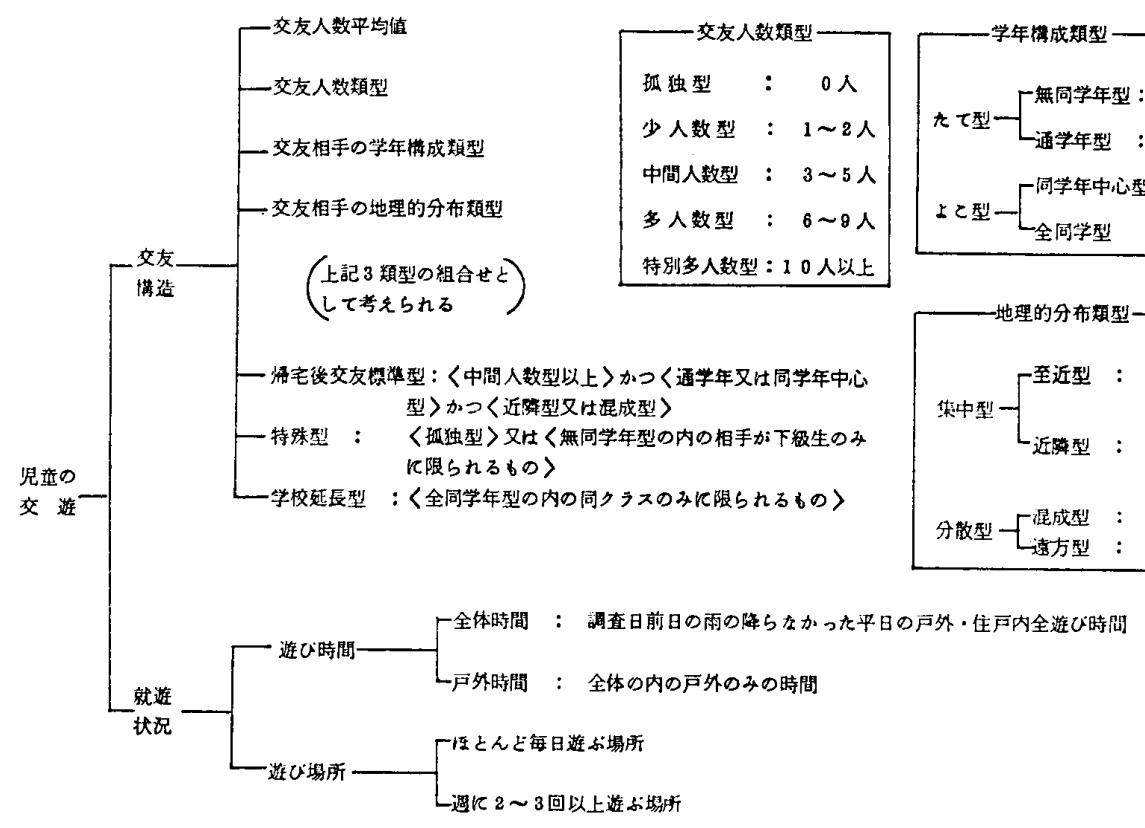

图一3 児童交遊偟関する各種指標 
表一3 各地区児童の地域活動参加率等

\begin{tabular}{|c|c|c|c|c|c|c|c|c|c|c|c|c|c|c|c|c|}
\hline \multirow{2}{*}{\multicolumn{4}{|c|}{ 地区 · 男女別 }} & \multirow{2}{*}{$\begin{array}{l}\text { 䌊 } \\
\text { (人) }\end{array}$} & \multirow{2}{*}{ 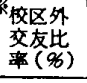 } & \multicolumn{2}{|c|}{ 地域团 体 } & \multicolumn{3}{|c|}{ 活助此率 (\%) } & \multirow{2}{*}{$\frac{\text { [月] }}{[\text { 回数不明 }}$} & \multirow{2}{*}{$\frac{i}{\text { 無 }}$} & \multicolumn{3}{|c|}{ 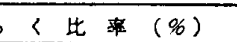 } & 〔週〕 \\
\hline & & & & & & 不㚛加 & 参加 & 1 2回 & $\overline{3 \sim 5 \text { 回 }}$ & 6回以上 & & & 有 & 1〜2回 & $3 \sim 4 \square$ & 5回该上 \\
\hline \multirow{2}{*}{ 既 } & \multirow{2}{*}{ 伝 } & & 子 & 125 & 2 & 51 & 49 & 4 & 12 & 31 & 2 & 78 & 22 & 11 & 7 & 4 \\
\hline & & & 子 & 124 & 2 & 76 & 24 & 4 & 4 & $\theta$ & 7 & 83 & 17 & 5 & 5 & 7 \\
\hline \multirow{2}{*}{ 住 } & 生 & & 7 & 243 & 13 & 66 & 34 & 15 & 14 & 4 & 1 & 77 & 23 & 11 & 9 & 3 \\
\hline & 里 & & $子$ & 234 & 12 & 78 & 22 & 12 & 10 & 0 & 0 & 75 & 25 & 8 & 12 & 5 \\
\hline \multirow[b]{2}{*}{ 地 } & 中 & & 子 & 108 & 3 & 62 & 38 & 3 & 13 & 22 & 0 & 81 & 19 & 13 & 4 & 1 \\
\hline & 浜 & & 子 & 87 & 2 & 85 & 15 & 2 & 11 & 2 & 0 & 89 & 11 & 8 & 3 & 0 \\
\hline \multirow{5}{*}{$\begin{array}{l}\text { 計 } \\
\text { 画 } \\
\text { 団 }\end{array}$} & \multirow{2}{*}{ 伝 } & 公 & 男 子 & 60 & 2 & 37 & 83 & 15 & 18 & 26 & 6 & 78 & 22 & 11 & 8 & 3 \\
\hline & & 团 & 女子 & 80 & 2 & 80 & 40 & 27 & 5 & 5 & 3 & 83 & 7 & 2 & 3 & 2 \\
\hline & \multirow{2}{*}{$i$} & 公 & 男子 & 84 & 2 & 46 & 54 & 7 & 39 & 6 & 2 & 86 & 14 & 9 & 0 & 5 \\
\hline & & 営 & 女 子 & B 7 & 0 & 71 & 29 & 8 & 15 & 6 & 0 & 80 & 10 & 7 & 1 & 1 \\
\hline & 中 & 捠 & 男女計 & 50 & 2 & 64 & 36 & 2 & 22 & 12 & 0 & 68 & 32 & 24 & 6 & 2 \\
\hline
\end{tabular}

\begin{tabular}{|c|c|c|c|c|c|c|c|c|c|c|c|c|c|c|c|c|c|c|}
\hline \multirow{2}{*}{\multicolumn{4}{|c|}{ 地区 · 男女別 }} & \multicolumn{5}{|c|}{ 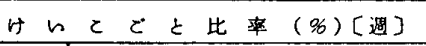 } & \multicolumn{3}{|c|}{ 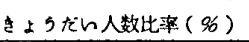 } & \multirow{2}{*}{$\frac{\text { 同 }}{1 \text { 人 }}$} & 窒 & t & \multirow{2}{*}{$\frac{1}{5 t 0}$} & 比 & \multicolumn{2}{|c|}{ 萧 $(\%)$} \\
\hline & & & & 無 & 有 & $1 \sim 2$ 回 & $3 \sim 4$ 回 & 55回以上 & 11 & 2 人 & 3人以上 & & 2 人 & 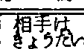 & & 3人以上 & 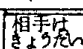 & 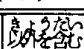 \\
\hline \multirow[b]{2}{*}{ 既 } & 伝 & 5 & 子 & 42 & 58 & 10 & 17 & 30 & 6 & 54 & 40 & 8 & 40 & 35 & 5 & 52 & 10 & 42 \\
\hline & 法 & & $子$ & 16 & 84 & 8 & 27 & 48 & 6 & 46 & 48 & 11 & 33 & 28 & $\mathbf{B}$ & 56 & 11 & 45 \\
\hline \multirow{2}{*}{$\begin{array}{l}\text { 成 } \\
\text { 住 }\end{array}$} & 生 & & 子 & 37 & 63 & 13 & 24 & 26 & 8 & 46 & 46 & 16 & 37 & 30 & 7 & 47 & 11 & 36 \\
\hline & 野 & & 子 & 18 & 82 & 14 & 25 & 43 & 5 & 53 & 42 & 14 & 32 & 26 & 6 & 54 & 8 & 45 \\
\hline \multirow{2}{*}{ 地 } & 中 & t & 子 & 27 & 73 & 12 & 36 & 25 & 10 & 51 & 39 & 20 & 34 & 27 & 7 & 46 & 4 & 42 \\
\hline & 捠 & & 子 & 18 & 82 & 14 & 35 & 32 & 9 & 53 & 38 & 8 & 28 & 21 & 7 & 63 & 7 & 56 \\
\hline \multirow{5}{*}{$\begin{array}{l}\text { 咶 } \\
\text { 画 } \\
\text { 団 }\end{array}$} & \multirow{2}{*}{ 伝 } & 公 & 男 7 & 45 & 55 & 23 & 17 & 15 & 14 & 55 & 31 & 23 & 41 & 34 & 6 & 36 & 9 & 27 \\
\hline & & 田 & 女子 & 25 & 75 & 20 & 32 & 23 & 5 & 62 & 33 & 7 & 44 & 39 & 5 & 49 & 15 & 34 \\
\hline & \multirow{2}{*}{$z$} & 公 & 男 & 44 & 56 & 13 & 11 & 33 & 2 & 50 & 48 & 3 & 52 & 41 & 11 & 45 & 16 & $2 \theta$ \\
\hline & & 밤 & 女子 & 27 & 73 & 10 & 13 & 49 & 4 & 39 & 57 & 4 & 43 & 37 & 6 & 52 & 28 & 24 \\
\hline & 中 & 兵 & 男女言 & 28 & 72 & 20 & 42 & 10 & 12 & 48 & 40 & 10 & 62 & 50 & 12 & 28 & 8 & 20 \\
\hline
\end{tabular}

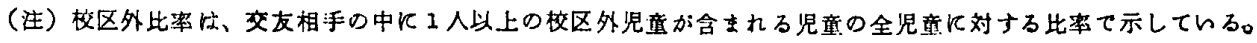

地区で $2 \%$ ないし $3 \%$ であるのに比べて生野地区は高 い。先にも述べたように，生野地区は3校区閒に通過道 路や河川などの明膫な物理的境界要素が無い地区である のに比べ，伝法と中浜の両地区は校区区域が通過道路と 河川あるいは大規模な非住宅用地によって比較的境界づ けが明膫でありまとまっている。この物理的条件の相違 が上記の結果と関連していると考えられる。

（2）地域団体活動参加状況 活動はどの地区でも 男子が女子よりも旺盛で，地区別には伝法の参加率（団 体に加入し実際に参加経験のある児童の比率）が高く, 1 ケ月単位でみた活動回数も多い。それに比べて生野地 区は参加率は必ずしも低いと言えないが，実際の活動回 数は少ない。団地は一般に参加率は既成住宅地よりも高 いが, 活動回数は多くない。

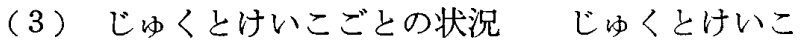
ごとの両方あるいはそのいずれかに行っているものの割 合をみてみると，女子が男子よりも高く女子で 7 割ない し 8 割台, 男子で 6 割ないし7 割台である。また,これら に通う程度は，そのどちらかに行く回数が週に 5 回以上 あるとするものが，公団団地ではやや低いが，公営団地 と既成住宅地では 3 割ないし 5 割あり, 頻繁に通ってい る者がかなり多いことが示されている。家庭教師につい ている児童は 3 地区ともほとんどいない。

（4）きょうだい人数 きょうだい人数は, 既成住
宅地ではほとんど差はないが，団地では公営団地が公団 団地よりもかなり多く,きょうだい 3 人以上の比率も公 営では 5 割強と高い。

（5）同室就寝状況 児童の 同室就寝人数の結果 は, 高密度住宅地における住宅条件の厳しさを反映して いるものと考えられる。3 人以上の同室就寝をしている 者が，既成住宅地ではいずれの地区でも 5 割前後ないし 6 割前後あり，団地では 3 割弱のやや低い森之宮団地を 除けば, 伝法の公営と公団団地ともに 4 割前後ないし 5 割前後ある。また，同室就寝の相手がきょうだい以外の 成人である者の比率も，少ないところで 3 割，多いとこ ろで 6 割と相当高い比率を示している。

\section{2 交友人数と遊び時間の分布傾向}

各地区における交友人数の度数分布と帰宅後の遊び時 間の度数分布から，それぞれの分布傾向をみてみる。

図一4 は各地区の既成住宅地と団地別の児童の交友人 数を相対度数分布で表わしたものである。それらをみて みると，(1) 男子は女子に比べて，人数の多い方の裾が 伸びてピークの山が低くなだらかである。(2) 友達無し とした者の比率は, 既成住宅地の方が団地より高い。ま た，団地男子で極めて多人数(図における 14 人以上を 指す）の交友を行っている者の比率がかなり高くなって いる点が目立つ。

図一5 は帰宅後（雨の降らなかった平日）の住戸内外 

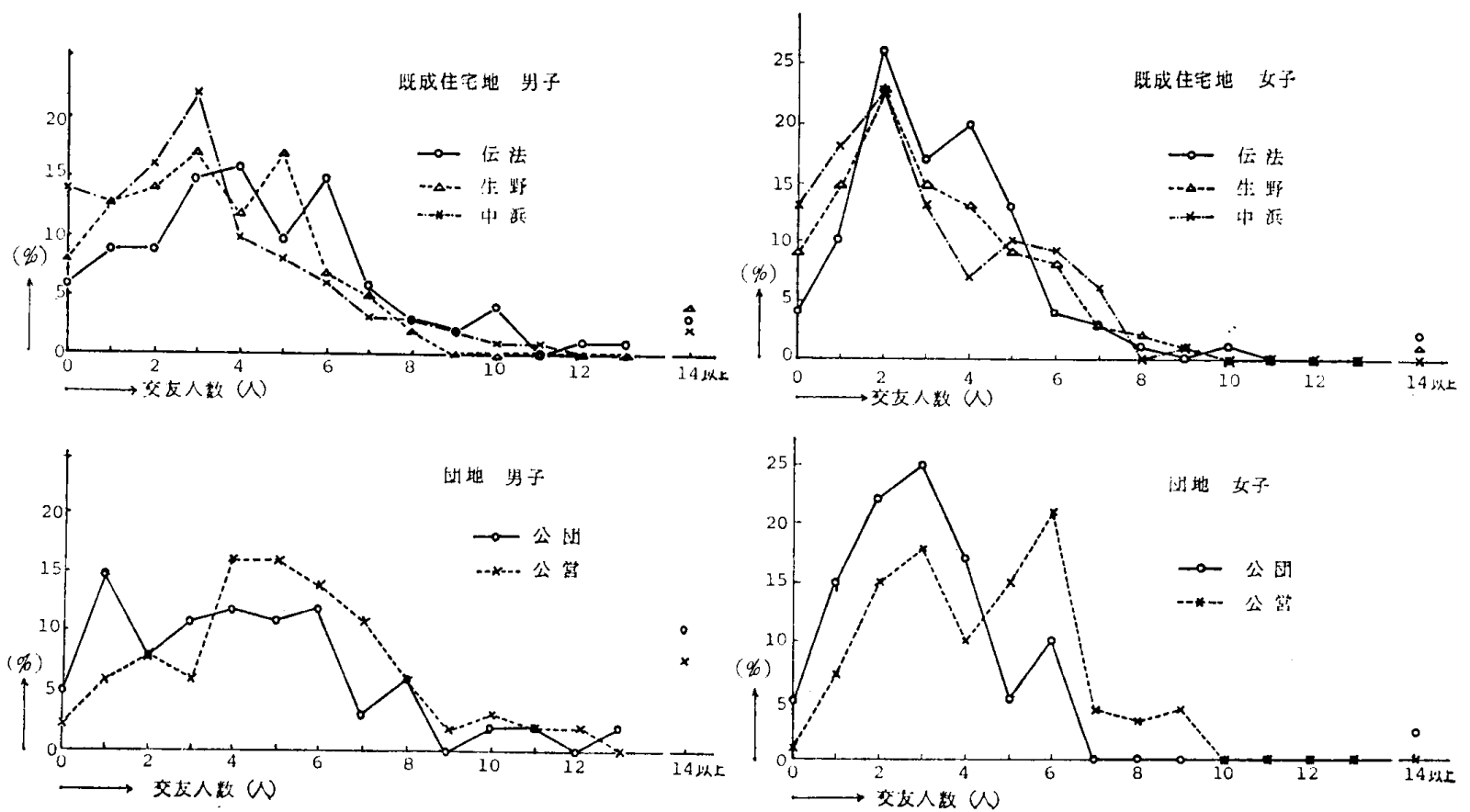

图-4 交友人数相対度数分布
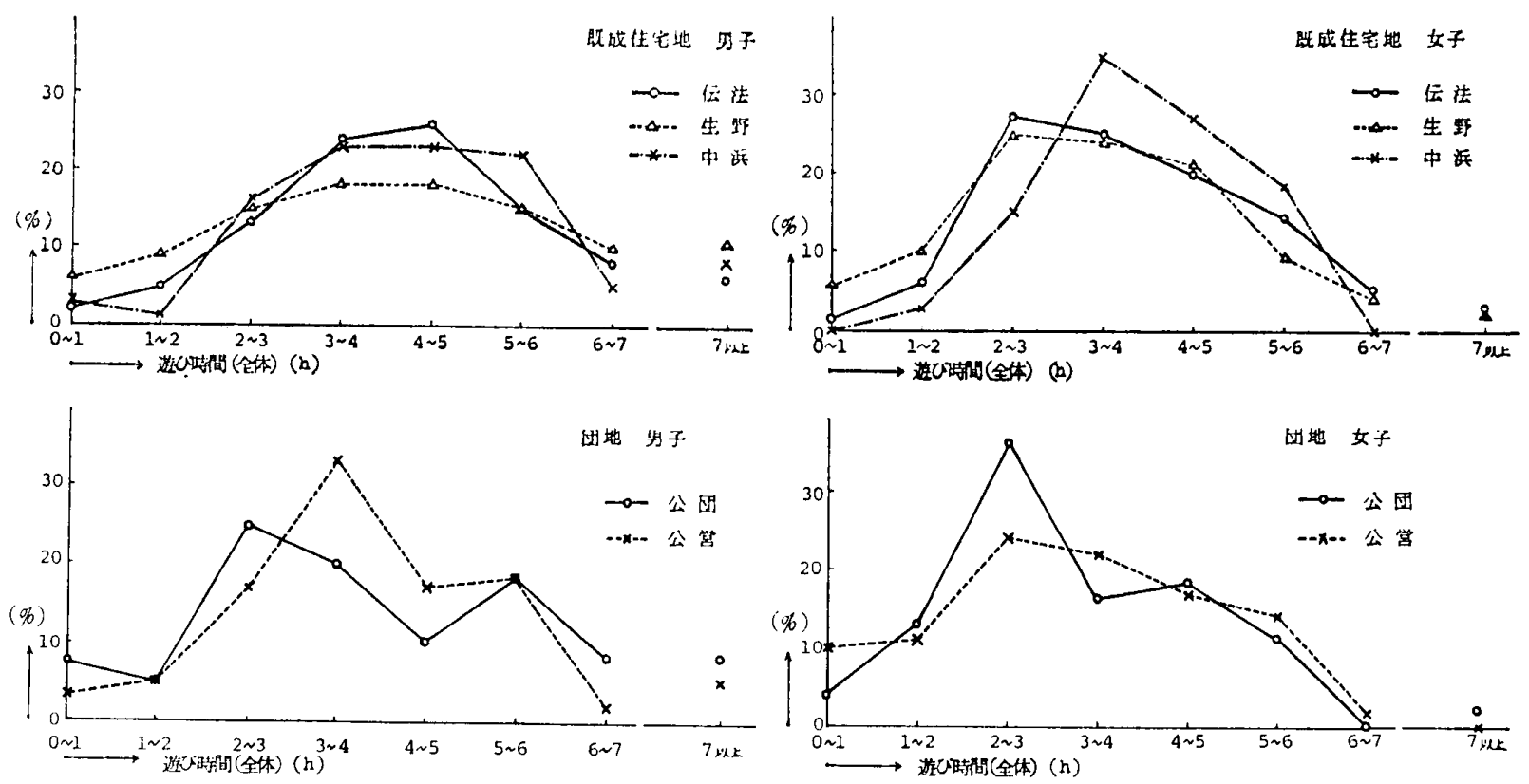

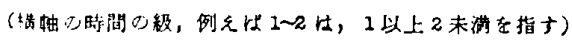

図-5 帰宅後遊び時間（全体）の相対度数分布
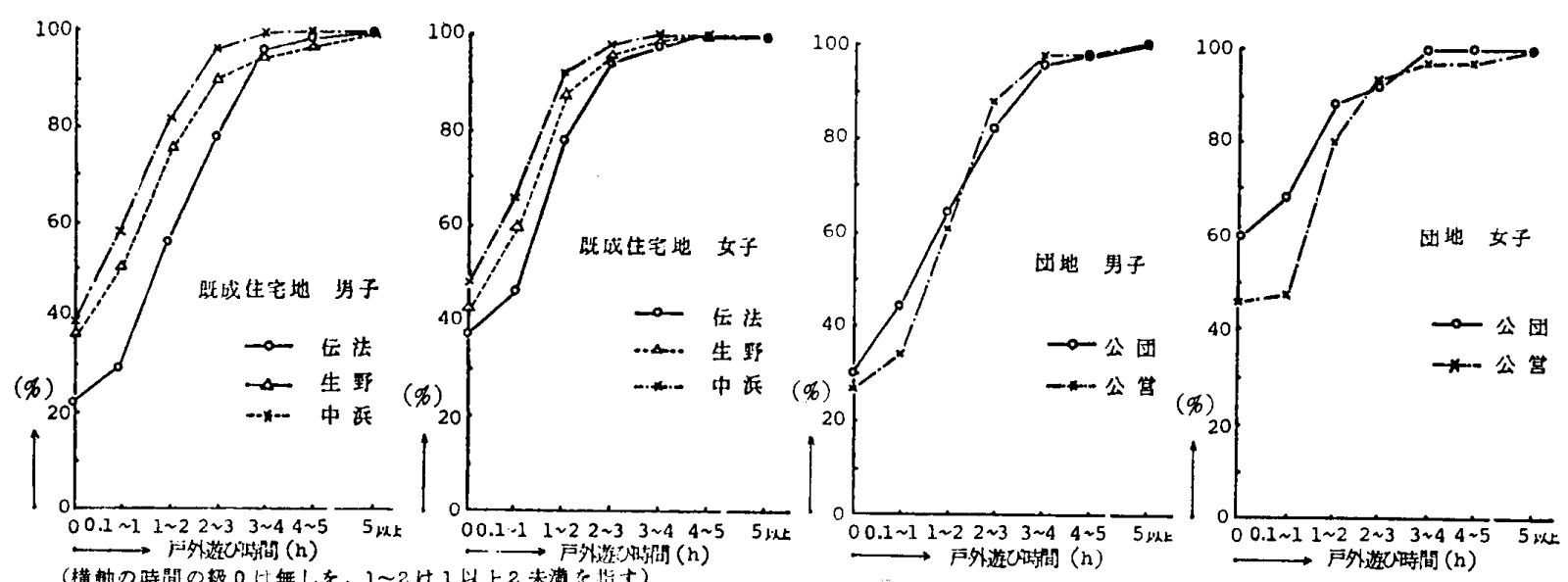

图一6 帰宅後戸外遊び時間の累積度数分布 
表一4 非物理的要因ならびに住宅条件別児童交遊集計結果表

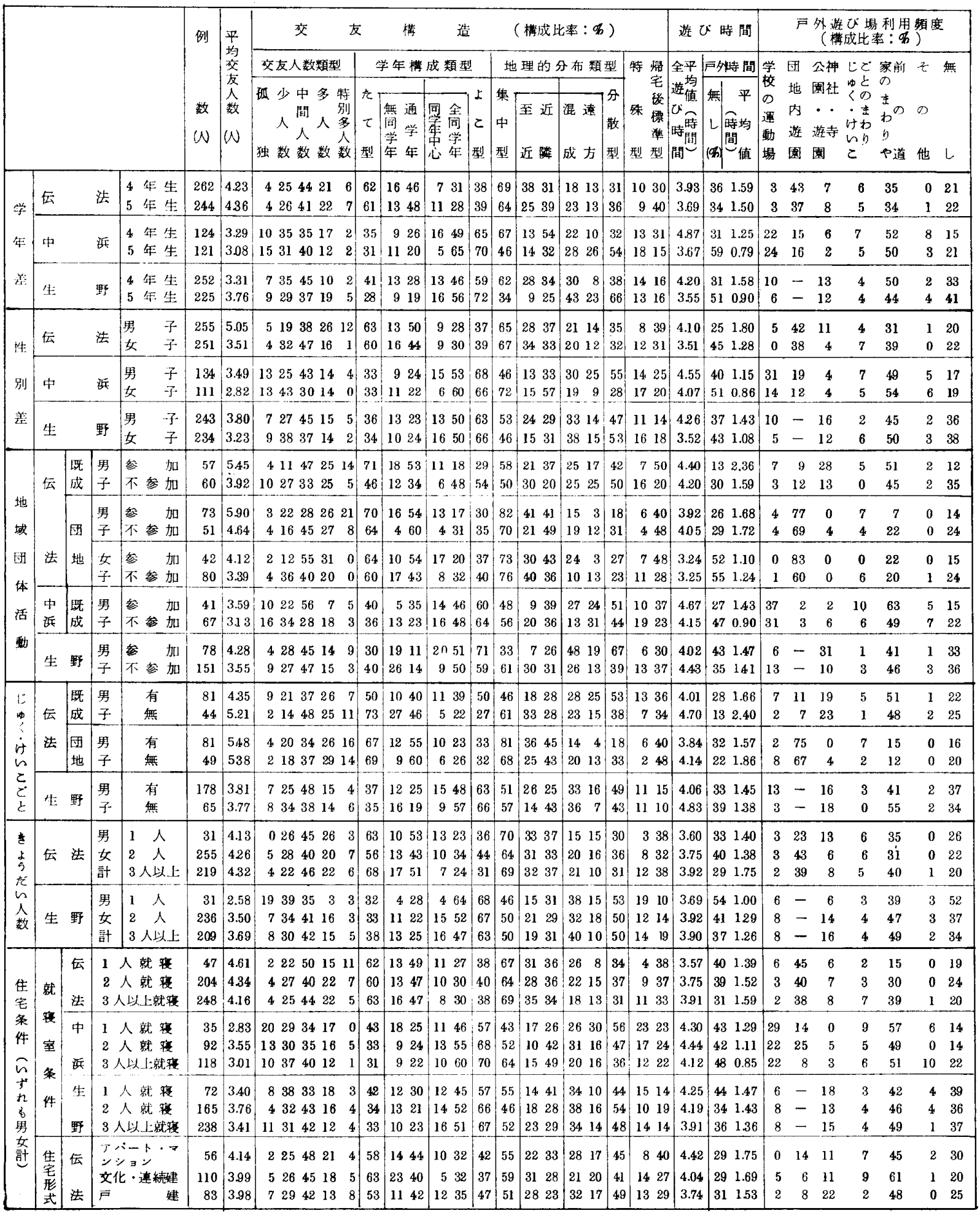

（注 1）表側の各項目についてのカテゴリの例数が 30 以上のものについて，各種指標の数值を载せた。この表では遊び場利用頻度のうち， 「ほとんど毎日遊ぶ場所」のみの結果を載女, 「週 2 回〜 3 回以上遊ふ場所」の結果, 並びに遊び時間についての戸外遊び時間／全体遊 び時間の比率の分布及び学校交友延脣型比率の集計結果を除いている。

（注 2）表頭の学年構成類型は交友人数 1 人以上について，地理的分布類型は交友人数 2 人以上について，それそれ集計したものである。

（注 3）表頭の戸外遊び場利用頖度は 2 ケ所以上を選択している者についてもそのまま菓郡しているので構成比率の合計は100\%を超える。

\section{全体の遊び時間を相対度数分布で表わしたものである。} これらをみてみると，(1) 男子は女子に比へて遊び時間 の折線が多い方に寄っている。特に，6時間以上遊ぶ者 の比率で男女の差に開きがみられる。(2) 既成住宅地で は中浜地区がやや多い方に寄っている。(3) 団地では公
営が公団よりも多い方に奇っている。

図一6 は帰宅後の戸外遊び時間を累積度数分布で表わ したものである。これらをみると，(1) 戸外遊び時間無 しとした者が，男子で 2 割ないし 4 割，女子で 4 割前後 ないし 6 割ありその比率が高い。(2) 既成住宅地の比較 
では，中浜地区が男女とも最も戸外遊び時間の少ない分 布傾向を示している。これは先の全体遊び時間で中浜地 区が多かったことを併せ考えると，この地区の全体時間 に対する戸外遊び時間の割合は相当低いものであること を示す。なお，これについては，次稿の既成住宅地の密 度の違いによる交遊の変動のところで触れるが， 3 地区 に分けた場合, 中浜地区の既成住宅地は密度が最も高く 遊び場等の不足が著しく，それが関係していると考えら れる。

\section{$\S 5$ 非物理的要因別の検討}

非物理的要因の各項目に関する児童交遊の各種指標の 集計結果は，表一4 の一部に示すとおりである。それら の分析結果を，(1) 4,5年生間の学年差, (2) 性別差, （3）地域団体活動の参加と不参加による差，(4) ビゅく とけいこごとの有無による差，(5) きょうだい人数の多 少による差，の各項目についてまとめると以下のようで ある。

(1) 4,5 年生間の学年差 交友人数忙 4,5 年生 の間に差はなく, 友達の学年構成では 5 年生は 4 年生に 比べてよこ型の比率がやや高く, 友達の地理的分布では 5 年生の方が分散型の 比率が高い。帰宅後の遊び時間 は， 5 年生の方が全体時間，戸外時間とも少なくなって いる。

（2）性別差 男子は女子に比べて交友人数がかな り多く, 交友人数類型でみると，少人数型 $(1 \sim 2$ 人) で女子が多く，特別多人数型（10 人以上）で男子が多く なっている。学年構成で差はみられず，地理的分布では 3 地区で男女差の一貫した傾向はつかめない。遊び時間 は全体時間，戸外時間とも男子が女子よりも多く，遊び 場への進出は男子が女子に比べて積極的である。

（3）地域団体活動の参加と不参加による差 参加 者の方が交友人数注多く, 特に活動回数の多い伝法男子 でその差は著しい。交友人数類型でみると，特別多人数 型の比率で参加者と不参加者の差が大きい。学年構成で は，参加者の方が伝法と中浜の両地区でたて型の比率が 高くなっているが，生野地区ではよこ型の比率が高くな っている。地理的分布では，一般に参加者の方が至近圈 集中型が少なくなるが，伝法の団地男子のみで参加者の 方が同一棟内に交友の限られる者の比率が不参加者のそ れよりも高くなっている。これは子供会等の構成単位 が，住棟グループでできていることと関係していると思 われる。地域活動は単に参加と不参加の相違だけでな く，それぞれの地区での活動の活発さや活動形態の相違 が関連するものと考えられる。

（4）じゅくとけいこごとの有無による差全般的 に，各地区でこの差による坚童交遊の一貫した変動傾向 がつかめない。ただ，遊び時間については，じゅくまた はけいこごとに行っている者の方が，生野地区での戸外
遊び時間を例外として，全体時間，戸外時間ともに，行 っていない者よりかなり少なくなっている。

（5）きょ5だい人数の多少による差 3 人以上き ようだいのある者の交友人数が， 2 人以下の者上り多く なっている。その他の交遊指標に関しては，各地区でき ようだい人数の多少による差はないか，もしくは，一貫 した変動の傾向としてつかめない。

\section{$\S 6$ 住宅条件別の検討}

住宅条件として，既成住宅地における住宅形式を，戸 建, 文化住宅一連続建, アパートーマンションに 3 分類 して，そこに住む児童問での交遊の相違を検討する。次 に，児童の同室就德人数を取り上げて，それの差異によ る交遊の相違がみられるかどうかを検討する。なおここ の同室就寝人数は，一応，児童からみた住宅における混 み合いを示寸一つの指標になっていると考えられる。

6.1 既成住宅地における住宅形式別の比較

戸建, 文化住宅一連続建, アパートーマンションに住 む巟童間の交遊の相違 をまとめると，下記のようであ る。

(1) 交友人数は，3者の間でその平均值及び人数類型 でみてほとんど差はなく, 学年構成では文化一連続建児 童の無同学年型比率がやや高い。地理的分布ではほとん ど差がない。

(2) 交友に関する総合的な指標でみてみると, 帰宅後 標準型は，アパートーマンション児童でその比率が高く なっているが, 特殊型並びに学校交友延長型の比率では 特別な差がみられない。

(3) 遊び時間は, 戸建, 文化一連続建, アパートーマ ンションの順で，全体時間が多くなり戸外時間もそれに 準じるが，顕著な差とは言えない。

(4) 遊び場所では, 文化一連続建览童の家のまわりや 前の道で遊ぶ率がやや高く, 戸建児童の公園, 遊園地, 神社等への進出率がやや高い。

全般的にみて，高密度な既成住宅地の住宅形式別にみ た児童交遊の相違は顕著ではない。

\section{2 就寝人数別の比較}

普段，家で寝るとき誰と同じ部屋で寝るかの回答をも とに, 同室就誛人数を 1 人就寝, 2 人就寝, 3 人以上就 寝の 3 者に分けて，それらの間での交遊の相違を比較す る。

中浜地区の 1 人就寝者が他に比べて，交友人数が少な い，学年構成における無同学年型比率が高い，地理的分 布に抢ける近隣型比率が低いなどのやや特徴ある傾向を 示しているが，伝法と生野の両地区では，3者の間で交 遊の各種指標を通じてほとんど差が認められない。特 に，住宅における個人的な場所の確保と住戸内，外の遊 び時間との間に何らかの関連があるのではないかと予想 されたが，中浜地区で就寝人数が多くなるにしたがい， 
戸外時間の減る傾向が認められるものの，他の 2 地区で は 3 者の間でほとんど差はない。

以上の結果から総括的に判断して，住宅における混み 合いを児童の同室就寝人数を指標としてみる限りで，住 宅における混み合いと児童交遊の間の一般的変動傾向は 捉めない。

[注]

1）密度効果の理論は, 動物の個体数変動が 種自身の個体間 の相互作用によって調節される点に注目しているもので, 個体群生態学における一つの主要な研究テーマになって いる。内田拨郎『動物の人口論』(1972) によると, 密度 効果とは単位空間内の個体数の多少によって増殖率が変 ってくるような現象を生息密度効果または単に密度効果 と呼んでいるとある。本文中に述べているフリーの原理 も, 社会性のある動物個体群では, 生活体の生存反応や 生長弯が, 密度の变化に対して中間の最適密度のところ を頂点とする山型のカーブを描くとしている点で,一つ の密度効果の理論であるとみることができる。

密度効果に関する言葉の使われ方は一定していない。 その使われ方の傾向として次のようなことが感じられる。 主として昆虫類を対象とした個体群生態学の分野では, 個体数の制御機構に関して density effect が用いられる が, 密度効果の確定的な意味あいを避けて effect of density が使われる場合もある。哺乳動物を対象とする領域 では，それらの言葉も使われるが, density syndrome あるいは effect of crowding が多く使われるようにな る。人間を対象とする領域では, effect of crowding が 多く使われ density effect は余り用いられない。また, 密度効果増殖や個体間相互作用に関乙て, 高密度な場 合のマイナスの影響のみについて使われる場合もあるし， 全体の密度域を通じてプラスとマイナスの両方の影響を 包含する意味で使われる場合むある。本論では，上記の 意味あいからいえば, effect of crowding を使うのが適 当であるかもしれないが, 数量的指標として密度そのも のを用いていることもあって, 密度の影響という言葉を 全般的に用いている。をた，その影響は本論では高密度 域のマイナスの作用に注目している。

2)これらの既往研究については, 拙稿「密度と社会的要因 （その 1. 既往研究と問題点)」, 昭 51 年建築学会大会梗 概集で，その大まかな内容と文献を紹介している。

3）(1) 斎藤和夫・川名吉エ門他「高密度住区における遊び 場一住街区形式と子供の遊び集団一」, 建築学会論文報告 集 54 号, 1956 年。

(1) 谷口沉邦「住宅団地内外のコミュニケーションにつ いて」, 建築学会論文報告集 69 号 II, 1961 年。
(1) では，児童密度と住街区形式の相違が，遊び集団の形 成に作用することが指摘されている。

(口) 及び一連の研究を通じて，谷口は，「物理的に近いこ とは交友選択の大きな動機糸っいるが,これは換言 すれば人口密度に関連している」,「人口密度との間に, ある種の比例関係が予想される」(『建築計画学 3 地域施 設教育』, 吉武泰水編, 1975 年)，「一般に戸数密度の上 昇（これは物理的な近接性を意味する）は，必ずしも綄 合的な交流率を高めることにはならない」(住宅地計画 における施設利用圈と生活領域論」『建築雑誌』, 昭 43 年 4 月号) と述べている。

4） L. Festinger (1950) の機能的距離と近隣のつきあいの 関係，L. Cuper (1953) の入口の位置とつきあいの関係 などをみた研究以来, 住戸の物理的配置上からくる接触 のしやすさと人の交際の間に関係のあることが, しばし ば指摘されている。

5) C. Hutt \& J. Vaizey (1966), I. Altman et al. (1967), C.M. Loo (1972) などの実験室的研究において, 詰め込 まれたり密度が高くなる状況では，孤立的行動が増えた り相互の交涉が減少することが指摘されている。また， 日常的には満員電車の中で乗客が互いに無関心になるよ うに振舞うことなどが指摘される。

6) J.B. Calhoun (1962) のネズミを使った「個体群密度と 社会病理」に関する実験研究の報告は有名である。K. Myers et al. (1971)のうさぎを使った研究でも「哺乳動 物において確に密度症候群が存在するという結論を得た」 （下記その他の参考文献（5）p. 149）としている。

7) W.C. ALee et al. 『Princeples of Animal Ecology , 1949 年。

E.P.オダム著・三島次郎訳『生態学の基礎 上』, 1974 年。

8）拙稿「密度と社会的要因（その2. 住宅地に打ける児童 の密度之交友構造)」，昭 51 年建筑学会大会梗概集。

\section{その他の参考文献}

1）伊藤嘉昭「密度効果とこみあい効果」『生物科学』，1973 年, 25 (3)。

2）伊藤嘉昭・桐谷圭治『動物の数は何で 決まるか』，1971 年, NHK ブックス。

3）厳 俊一「こみあいの生態学」『自然』, 1971 年, 12 月号。

4） W. マイケルソン著・栄久庵祥二訳『住環境計画』, 1975 年, 鳳山社。

5) A.H. Esser Ed. Behavior \& Environment--The Use of Space by Animals and Men PLENUM PRESS。

6）谷口沉邦・森保洋之他「市街地計画住区及びその周辺住 区における住民の近隣交流に関する研究一高層高密度住 宅団地計画の研究・その 9-」, 昭 49 年建築学会大会梗 概集。 


\title{
S Y N O P I S
}

U.D.C. 711.582

\section{THE EFFECTS OF DENSITY ON THE CHILDREN'S FRIEND- FORMATION IN RESIDENTIAL AREAS (Part I)}

\author{
by RINTARO KAWAMICHI, Lecturer of Kansai Univ. Member \\ of A.I.J.
}

The aim of present study is to examine the effects of density on human interpersonal relationships in daily-life settings. It was designed to explore relationships between the density and the children's friend-formation in residential areas. An investigation was conducted about children's friends and their play after school at primary schools in high density areas. The subjects were boys and girls aged 10 and 11 . The density was measured by using the area of a housing block and a school district as the denominater respectively. The friend-formation was intended to be grasped through three elements; the number of friends, the friends' composition on school year and their geographical distribution. Children's play was measured through two aspects of time and place. In this first paper several items were examined before beginning the discussion of relations between the area's density and the children's friend-formation. Their items were concerned with several non-physical factors, the housing type and the crowding in dwellings. As a result of their examinations it was found that there were differences in the friend-formation between male and female and between participants and non-participants in the activities of community-group and that there were scarcely connected with the housing type and the crowding in dwellings. 